\title{
Internet resources for the earth sciences
}

\author{
By Flora Shrode Cobb and Edward F. Lener
}

\section{Finding those gems in the rough}

$\mathbf{T}$ he funclamental goal of earth science investigations is to understand the geologic processes affecting the world around us. Some of the better-known concentrations in the field are: assessment of energy and mineral resources, establishment of factors that affect land use and maintenance of environmental quality, and seeking to understand the nature and mitigate the impacts of geologic hazards such as earthquakes, volcanic eruptions, and landslides. Internet resources in earth sciences have been developed by a diverse range of groups inclucling universities and other educational facilities, research organizations, federal government agencies, publishers, and private industry. Gopher, ftp, and World Wide Web (WwW) home page sites make it possilble to gatin access to data sets, publications, software, directories to agencies and personnel, and educational materials. In addition, Internet sites will often cross-reference one another enabling the searcher to find information on other host computers.

Earth sciences is a very broad field and has interdisciplinary ties with many other areas. This resource guide offers a sampling of key sites which focus on such aspects of geology as structural geology, geophysics, geochemistry, mineralogy, geomorphology, and hydrogeology. The purpose of this guide is to offer brief descriptions of several prominent sites which exemplify the types of tools and information available over the Internet. Numerous other sources are available which address fields related to geosciences, such as geographic information systems (GIS), cartographic and mapping tools and data, climatology, environmental science, and space and planetary sciences, to name only a few. In general, sources listed here serve as starting points to uncover links to data resources and directories in more specialized areas.

Sources listed here come predominately from the United States, although there are a few international listings. Be aware that the changing nature of the Internet may result in some of the addresses listed here being incorrect at the time the reader tries to connect. An excellent, nearexhaustive tool for anyone exploring Internetaccessible resources in earth and environmental sciences is Bill Thoen's On-line Resources for Earth Scientists (ORES) which is available from ftp://ftp.csn.org/COGS/ores.txt. Many of the tools described here are listed in the Geology and Geophysics section of 'Thoen's list.

\section{Major government agencies}

- United States Geological Survey (USGS). USGS Home Page. Access: http:/ www.usgs.gov/. The USGS Home Page is always evolving and now includes a publications catalog and full text of some USGS items, in clucling titles in the Open File Reports series. Announcements, news reports, and information about educational resources and services offered by the USGS are posted and regularly updated. Along with providing information about the agency, the home page serves as a link to many more specialized sites such as volcano observatories, the National Geophysical Data Center, and other Internet sites affiliated with the USGS or covering related topics.

Flora Shrode Cobb is reference coordinator, science and technology, at the University of Tennessee Libraries, Knoxville, e-mail: cobb@utklib.lib.ulk.edu; Edward F. Lener is science reference librarian at Virginia Polytechnic Institute and State University Libraries, Blacksburg, e-mail: lener@utum 1.cc.vt.edu 
The USGS offers a registry of Earth and Environmental Science Internet Resources (http:/ /www.usgs.gov/network/science/earth/ earth.html) which is a useful collection of Internet resources with links to dozens of sites around the world.

- United States Bureau of Mines (USBM). Access: http://www.usbm.gov/. This home page offers general information about the history and objectives of the USBM and its organizational structure. Other options on the introductory menu are a gateway to other Internet-accessible services from the USBM and a bimonthly list of new publications that are available.

- USDOC/NOAA/NESDIS/ National Geophysical Data Center. U.S. Dept of Commerce (USDOC), National Oceanic \& Atmospheric Administration (NOAA), National Environmental Satellite, Data and Information Service (NESDIS). Access: http://www.ngdc.noaa.gov/ aboutngdc.html. The National Geophysical Data Center (NGDC) supports national research on the environment and offers public domain data to a wide user community. Major fields for which the center manages data are solar-terrestrial physics, solid earth geophysics, marine geology and geophysics, paleoclimatology, and glaciology. NGDC maintains Geophysical OnLine Data (GOLD) which contains over 300 digital and analog databases, many of which are accessible via Web browser software, gopher, and anonymous ftp. In addition to work on cooperative projects with government agencies, universities, and nonprofit organizations in the U.S., it interacts with foreign scientists to foster global information exchange.

- Sandia National Labs Geoscience \& Geotechnology Center. Access: http:// sair019.energylan.sandia.gov: $70 / 0 /$ Sandia Geosciences/center.html. The Geoscience and Geotechnology Center initiates and manages projects that Sandia National Labs carry out in the oil, gas, and geothermal industries. The

\section{Correction}

In the "Internet resources for education" article in the March issue of CERL News we inadvertently gave the wrong address for the listserv KIDLIT-L. The correct address is: KIDLIT-L@bingvmb.cc.binghamton.edu. The editors regret the error. center supports basic geoscience research and technology development for energy recovery and storage, disposal of radioactive waste, and remediation of contaminated sites.

- British Geological Survey (BGS). ACcess: http://www.nkw.ac.uk/bgs/home.html. BGS, the national geological survey of the United Kingdom, was founded in 1835 and provides geological information for the land and offshore areas of the United Kingdom and the nearby continental shelf. The home page contains information about BGS publications, datasets, and archives.

- World Data Centers. Access: http:// www.ngdc.noaa.gov/wdcmain.html. Established in 1957, World Data Centers first originated in the International Geophysical Year (IGY). At last count there were 44 centers in the World Data Center system although many are not yet Internet-accessible. Centers are funded by national institutions, such as NOAA's NGDC, and are located in the U.S.A., Russia, Europe, Japan, India, and China. Their work is intended to make data available to scientific workers in all countries. The International Council of Scientific Union's (ICSU) Panel on World Data Centers and its predecessor bodies set guidelines which govern the cen ters' activities.

\section{Research and educational institutions and associations}

Many research and educational institutions and associations offer information about courses of fered and directories of staff with their research interests. Introductory menus may offer an option to get information about the Internet in general and about software used to browse resources. Items appearing on menus often connect to other institutions' gophers and WWW home pages. In some cases, a host site for a Web page or gopher system may offer access to specialized services for users in its institution's community. Such services are usually limited by contractual agreements to use by members of the primary community, and menu items may indicate such restrictions by a note such as "limited access," or "IInstitution Name] access only."

\section{- Geological Society of America (GSA).}

Access: http://www.aescon.com/geosociety/ index.html. The society's home page offers a membership directory, calendar of meetings, guide to society awards and grants, and link to the GSA Institute for Environmental Education. 
- Colorado School of Mines. Access: http://gn.mines.colorado.edu/ $1 /$. This site is a very typical university WWW home page with the school's course catalog, directory of personnel, and calendar posted. The section called "World Resources and Services" leads to Colorado gopher services, U.S. government information, library resources such as reference tools, electronic books and selected journals, and Internet-accessible library catalogs, and other Internet services.

- Earth Sciences and Resources Institute (ESRI). Access: http://www.esri.utah.edu. A university-based (University of South Carolina and University of Utah) geoscience research organization, ESRI conducts national and international multidisciplinary research related to the earth sciences, including the disciplines of geology, geohydrology, geothermal, geophysics, and geochemistry. The Institute provides educational opportunities for advanced degrees in technical and managerial preparation for students working on projects within these and related disciplines.

- Pennsylvania State University. Earth System Science Center: access: http:// www.essc.psu.edu/; College of Earth \& Mineral Sciences: access: http://www.ems.psu. edu/. The Earth System Science Center is formed by Penn State's departments of Geosciences, Meteorology, Geography, and Mineral Economics. Research emphases are the global water cycle, biogeochemical cycles, and human impacts on the Earth system. Of particular interest are the pointers to over 140 additional earth science education resources. The College of Earth and Mineral Sciences home page offers descriptions of undergraduate and graduate programs, directories of the faculty and students involved, and information about Penn State computing services and educational facilities.

- MIT Earth Resources Laboratory (ERL). Massachusetts Institute of Technology (MIT). Access: http://www-erl.mit.edu/. Research at MIT's ERL focuses on applied geophysics as it relates to tectonophysics, seismology (especially seismic exploration), environmental engineering, and parallel computing. Special topics for which pointers are available include the Borehole Acoustics and Logging Consortium, the Center for Advanced Geophysical Computing, the Global Positioning System [GPS], and New England Seismic Network / MIT.
- Earthquake Information Gopher from the National Information Service for Earthquake Engineering (NISEE). Access: gopher://nisee.ce.berkeley.edu:70/1. This gopher is a public service project of the Earthquake Engineering Research Center at the University of California at Berkeley and is designed to gather information on earthquake engineering, earthquake hazard mitigation, earthquake disaster response, and related subjects.

- CIESIN. Consortium for International Earth Science Information Network. Access: http://infoserver.ciesin.org/usda/usdahome.html. CIESIN supports efforts of the USDA's Global Change Program Office to document the results of ongoing global change studies in agriculture and forestry. Projects undertaken by the Consortium emphasize preservation and dissemination of data useful in policy making and research on agricultural productivity, soil erosion, irrigation water demands, and water quality.

- Global Change Data and Information System (GCDIS). Access: gopher://gopher. gcdis.usgcrp.gov:70/. Established by the Committee on Earth and Environmental Sciences (CEES) in response to the Global Change Research Act of 1990, the GCDIS is designed to facilitate access to global change data and information for members of the United States Global Change Research Program (USGCRP), members of academia, and the international community.

- University of California Museum of Paleontology. Access: http://ucmp1 berkeley. edu/. Displays interesting exhibits, an educational Geological Time Machine, and links to other major sites for paleontology.

- University of Washington Geophysics Program. Access: http://www.geophys. washington.edu/ or http://www.geophys. washington.edu/seismosurfing.html. In addition to offering descriptions of specialized research programs at the University of Washington, this site offers an extensive directory of resources for seismic information.

\section{Funding sources}

- NSF Science and Technology Information System (STIS). Access: gopher:// stis.nsf.gov:70/11/ or http://www.nsf.gov/. The National Science Foundation's (NSF) gopher offers access to NSF publications organized by the NSF Directorate that published the docu(Internet cont. on page 325) 
skills, creativity, incentive, flexibility, teamwork, and problem-solving skills are incorporated.

The seminar's participants were well informed on issues of American and British librarianship. They were enthusiastic and committed to their jobs, eager to make the necessary changes, receptive to ideas, and had viable solutions to their problems. Most have e-mail addresses and are eager to establish contact with libraries abroad. The majority of represented libraries are automated or will be soon.

I was very impressed with the Copernicus University Library, a leader among Polish libraries and a pioneer on several fronts. Under the dynamic leadership of director Stefan Czaja, it is the first library in Poland that changed its organization into a less bureaucratic, more democratic and user-friendly one. After an indepth study of integrated library systems, it purchased the one meeting its specific needs. The library, now preparing to convert to open stacks, will be the first library in Poland, perhaps in Eastern/Central Europe, to do so
Our hospitable and gracious hosts organized a tour to the beautiful University of Gdansk Library and the Solidarity Plaza and Monument. We visited the magnificent cathedral at Pelplin and saw the "Gutenberg Bible." We attended a concert on the ancient organs at the cathedral in Oliwa, and another one by the Torun Orchestra where a Russian female soloist played Chopin exquisitely. Very impressive was the visit to the Teutonic Knights medieval castle in Malbork dating back to the 13 th century. And the ancient town of Torun, the birthplace of Nicholas Copernicus, gave us much to ponder.

Since my last visit to the Copernicus Library in May 1993 many user-friendly changes occurred. Most striking were increases in automation, signage, and the establishment of reference services. I came back convinced that contact with European libraries is beneficial and enriching to all, and welcome by our colleagues abroad. It is eviclent that our common missions, goals, problems, and solutions far outweigh our differences.
(Internet cont from page 321)

ment. Two indexes assist in locating specific documents available for retrieval, and the index to award abstracts is searchable.

\section{Ftp sites for software and documents}

- Computer-Oriented Geological Society (COGS). Access: ftp://ftp.csn.net/.

- National Spatial Data Infrastructure (NSDI) MetaData Sites. Access: ftp:// ftp.blm.gov/pub/gis/nsdi.html. Clearinghouse provides a pathway to find information, or metadata, about geospatial data available from USGS.

\section{Internet finding tools}

- EINet Galaxy. Access: http://galaxy. einet.net/galaxy/Science/Geosciences.html.

- WWW Virtual Library. Access: http:// www.geo.ucalgary.ca:80/VL-EarthSciences.html.

- Yahoo Server at Stanford University. Access: http://akebono,stanford.edu/yahoo/Science/Geology_and_Geophysics/.

\section{Usenet groups and mailing lists}

Usenet news groups and electronic mailing lists create a means for practitioners in the field to share research findings, discuss problems, announce conferences and events in the field, and pose questions to groups of people with common interests and expertise.

\section{Usenet groups}

- sci.geo.geology. This is the primary newsgroup for geology with discussion of general interest geological topics.

- sci.geo.hydrology. Discussion forum for topics in surface and groundwater hydrology.

- sci.geo.earthquakes. Discussion list for seismological topics and earthquake activity.

\section{Mailing lists \\ - GEOLOGY. Subscribe: listserv@ptearn. bitnet. \\ - GEONET-L. Subscribe: listserv@iubvm.} bitnet. Geoscience librarians and information specialists.

- HYDROLOGY. Subscribe: listserv@eng. monash.edu.au. Hydrology topics from Monash University in Australia.

- QUAKE-L. Access: ftp://vm1.nodak.edu/ LISTARCH/QUAKE-L and listserv@vm1.nodak. edu or listserv@ndsuvm1.bitnet. General earthquake discussion.

- SEISMD-L. Subscribe: listserv@bingvmb or listserv@bingvmb.cc.binghamton.edu. Seismological discussion. 